Boise State University

ScholarWorks

Organizational Performance and Workplace

Learning Faculty Publications and

Department of Organizational Performance and

Presentations

Workplace Learning

$10-2019$

\title{
Warriors in Suits: A Bourdieusian Perspective on the Construction and Practice of Military Masculinity of Korean Men
}

Jin Lee

Texas A\&M University

Melika Shirmohammadi

Idaho State University

Lisa M. Baumgartner

Texas A\&M University

Jihye Oh

Texas A\&M University

Soo Jeoung Han

Boise State University

This is the peer reviewed version of the following article:

Lee, J.; Shirmohammadi, M.; Baumgartner, L.M.; Oh, J.; \& Han, S.J. (2019). Warriors in Suits: A Bourdieusian Perspective on the Construction and Practice of Military Masculinity of Korean Men. Gender, Work \& Organization, 26(10), 1467-1488.

which has been published in final form at doi: 10.1111/gwao.12358. This article may be used for non-commercial purposes in accordance with Wiley Terms and Conditions for Self-Archiving. 


\title{
Warriors in Suits: A Bourdieusian Perspective on the Construction and Practice of Military Masculinity of Korean Men
}

\author{
Jin Lee \\ Department of Educational Administration and \\ Human Resource Development \\ Texas A\&M University \\ Melika Shirmohammadi \\ Department of Organizational Learning \& \\ Performance \\ Idaho State University \\ Lisa M. Baumgartner \\ Department of Educational Administration and \\ Human Resource Development \\ Texas A\&M University
}

\author{
Jihye Oh \\ Department of Educational Administration and \\ Human Resource Development \\ Texas A\&M University \\ and \\ Soo Jeoung Han \\ Department of Organizational Performance and \\ Workplace Learning \\ Boise State University
}

\begin{abstract}
Within masculinity scholarship, there is a gap about how masculinity carries over from a broad social context to an organizational context. This article explores the construction and capitalization of masculinity through a series of experiences in social fields such as the military and college, and the transfer of militaristic masculinity into the workplace. Drawing on grounded theory methods, we conducted in-depth interviews with 20 Korean men who completed their mandatory two-year military service and subsequently joined large corporations in Korea. We uncovered a four-phase model that depicts how Korean men's masculinity is constructed during military service and transferred to their organizational positions characterizing them as warriors in suits. Informed by a Bourdieusian perspective, this study shows how masculinities are constructed, reinforced, and legitimatized by the structural influences of society, and how the masculinity becomes the desired image of men at work, which perpetuates the gender and power gaps among organizational members.
\end{abstract}

Keywords: masculinity, military masculinity, theory of practice, Bourdieu, South Korea

It is literally military. The college and my company resemble the military... I learned the basics [of how to be a man] in the military, practiced it in college, and now I am using it in the company...

(Interview with a study participant)

Gender is embedded in everyday life and individuals cannot separate themselves from the practice of gender (Knights \& Willmott, 1985; West \& Zimmerman, 1987). Gender is continuously constructed, reproduced, and sustained through its everyday practice (Knights \& Tullberg, 2012). Practicing masculinity has gained burgeoning attention from scholars in gender and organization studies since West and Zimmerman's (1987) conceptualization of doing gender (Nentwich \& Kelan, 2014). The discourse around masculinity at work has also called for a recognition of gendering practices (Martin, 2001; 2006). To deconstruct the dominance of hegemonic masculinity and gender binary at work, one must understand how the masculinities are constructed, enacted, and sustained in individuals' life, work, and the broader social context (Gherardi, 2009; Knights \& Tullberg, 2012; Pullen \& Simpson, 2009). 
Gender and organization researchers have studied how hegemonic masculinity is constructed in a specific context. The military among others contribute to the construction of masculinities through intense socialization processes (e.g., Barrett, 1996; Hale 2012). Further, gender and organizational studies have studied the construction and practice of military masculinity (e.g., Gill, 1997; Klein, 1999; Lahema, 2005). In particular, scholars have revealed how military masculinity is constructed through the military training (Hinojosa, 2010; King, 2007) and the transition from military to civilian life (Higate, 2001; Karner, 1998).

What is less understood is how the military masculinity is transferred to the other social contexts (e.g., an organization) (Martin, 2001; 2006) and how it perpetuates the gender binary and power gaps among organizational members. Previous masculinity studies have not explored the mobility of masculinity practices and the connection among social contexts within which masculinity is constructed and enacted. By investigating the linkage between military and other civilian contexts (i.e., college or workplace), we expand our understanding of the origin of hegemonic masculinity at work and the way it subordinates femininities and other masculinities (Knights \& Kerfoot, 2004).

Our study is informed by Bourdieu's (1977) Theory of Practice, which explains how the mobility between social spaces is controlled by habitus - a durable and transposable system of individual dispositions. Individuals who share the same habitus build reciprocal and amicable relationships in certain social spaces. This theoretical lens is particularly associated with the gender binary and the reproduction of asymmetrical relations of power at work (e.g., Knights \& Kerfoot, 2004; Knights \& Willmott, 1985). Hegemonic masculinity as the configuration of gendered practice can be considered a habitus shared by dominant men in an institution (e.g., Martin, 2003; Nentwich \& Kelan, 2014).

Bourdieu's (1977) theory emphasizes that habitus is a cultural capital and transposable beyond one field. In a sexist society, hegemonic masculinity is an example of cultural capital. Men are considered superior to women. This male power advantage is perpetuated in society (Knights \& Willmott, 1985). We want to trace the process of constructing masculinities and its functioning as a legitimized cultural capital at work by studying the lived experiences of men as expanded across various social contexts: military, college, and organization.

The context of this study is South Korea (Korea, hereafter) where more than $70 \%$ of men serve the military before completing college and pursuing employment (Korea National Statistical Office, 2016). In their early 20 's, the majority of Korean men experience a militaristic culture through a two-year mandatory military service that significantly impacts their masculinity. This 'imprinted' military masculinity is then sustained and re-activated at workplaces where hegemonic masculinity is favored as a virtue of employees (e.g., Cho et al., 2016; Won, 2016), and operates as a vehicle to mobilize the corporate ladder.

In sum, our study explores the process of military masculinity and how it is practiced outside of the military from men's point of view. Specifically, we want to know: (1) How do men construct their military masculinity? (2) How is military masculinity practiced in the workplace? And (3) How does military masculinity perpetuate gender and power hierarchies in the workplace? Answers to these questions will deepen our understanding of the construction of military masculinity and its mobilization at work and will add to our understanding of "doing gender," as conceptualized by Bourdieu, in Korea.

\section{Masculinities as Configurations of Social Practice}

Masculinity has been traditionally defined to be hegemonic in that it reflects the ideal image of men upheld by organizational or societal norms (Barrett, 1996). According to Connell (1995), hegemonic masculinity is "the configuration of gender practice which embodies the currently accepted answer to the problem of the legitimation of patriarchy, which guarantees the dominant position of men and the subordination of women" (p. 77). Hegemonic masculinities are at the top of gender hierarchy (Hinojosa, 2000). Connell (1987) unveiled how hegemonic masculinity's power and dominance is shown and reinforced through every day social interactions. (Connell, 1987, 1995; Simpson, 2004).

Recently, masculinity scholars have focused on how gender is enacted or practiced at work as the underlying mechanism of polarized gender equality (Kelan, 2018; Knights \& Tullberg, 2012; McNay, 1999). The regime of hegemonic masculinity and gender binary is continually repeated, reproduced and sustained 
through the socially and culturally practiced masculinity (Knights \& Tullberg, 2012). In this view, enacting gender identity is then connected to 'doing gender' (Martin, 2003, 2006; West \& Zimmer, 1987). These perspectives conceptualize gender identity (i.e., masculinity or femininity) as an ongoing activity being "said and done" (Martin, 2003, p. 344) within everyday life, hence, it is situated and gendered social practice (Gherardi, 2009; Nentwich \& Kelan, 2014; Pullen \& Simpson, 2009). Namely, hegemonic masculinities are configurations of gendered practice in everyday lives (Connell, 1987, 1995; Knights, 2015).

Researchers in gender and organization have studied the multiplicity of gender identity-masculinitiesand its construction (e.g., Collinson \& Hearn, 1994; Linstead \& Pullen, 2006) suggesting that different masculinities characterize occupations, organizations, and social contexts (e.g., Barret, 1996; Woodward \& Neil Jenkings, 2011). For instance, Barret (1996) found that different sub-communities in the U.S. Navy show different masculinities. Aviators consider autonomy and risk-taking propensity as their masculine while perseverance and endurance reflect warfare officers' masculinities.

Practicing masculinities are very hegemonic, and manifested with multiple ways (Kelan, 2018); Men bond with other men by building informal work relationships, protecting and supporting each other, or even by sexually objectifying women at work. Also, men distance themselves from women by excluding or publicly criticizing them. Men impress others through self-promotion or by exerting dominance over other men and show that they are heroic by the manifestation of behaviors such as being entirely dedicated to working, fiercely competitive, and displaying rationality. These practices of doing masculinities enforce gender binary and polarizing hierarchies in organizations (Kelan, 2018), and ultimately fuel social and gender inequalities. Indeed, how masculinity is constructed and enacted cannot be separated from the social inequities in which it occurs (Bourdieu, 1990; Kelan, 2018).

Finally, practicing masculinities has been combined into the managerialism and sustained men's dominance in the organization. It has been argued that the agentic nature of traditional constructions of hegemonic masculinities—being aggressively competitive, goal driven, and instrumental-is something desirable to the pursuit of organizational success (Kerfoot \& Knights, 1998). Therefore, becoming a senior manager or climbing the organizational hierarchy is accompanied by the process of doing masculinity (Knights \& Tullberg, 2012).

\section{Construction and Practice of Military Masculinity}

The hierarchical structure of the military allows one to easily see how hegemonic masculinity could be constructed because men with the certain position have dominance over other men and women (Hinojosa, 2010). Military masculinity, as a form of hegemonic masculinities, mirrored an image of the warrior hero, who has a strong mentality, goal-oriented attitude, is physically fit, emotionally controlled, risk-taker, and heterosexual (Woodward, 2000).

When young men enter the military, they endure a robust socialization process that reinforces military masculinity (Hinojosa, 2010; Kimmel, 2000; Sasson-Levy, 2003). This masculinity is reinforced through such activities as boot camp and training that emphasizes a cohesive community (Hale, 2012). These activities serve two purposes: to create "real men" through physically and mentally challenging activities and to create good citizens (Cowan, 2008; Lahelma, 2005). By enduring tasks that are mentally and physically challenging, men arguably go through a rite of passage, but in the process, they construct artificial manhood rather than an inherently given masculinity (Goldstein, 2001; Kimmel \& Messner, 2009). Men who complete military service are seen as being of sound mind and body and more prestigious careers than those who do not complete military service (Levy \& Sasson-Levy, 2008). Hence, these constructed images of masculinities as "ideal men" or "good citizens" through military service contribute to class inequalities and legitimizing hegemonic masculinity by "molding the soldiers' conceptions of citizenship" ( $p$. 350).

In relation to the themes of military masculinity and its practice, several studies focus on men's lived experience in the military: the corporeal and embodied aspects of military masculinity (e.g., Gill, 1997; Klein, 1999; Lahema, 2005), how military masculinity is constructed and inculcated through military practice and training (Hinojosa, 2010; King, 2007), and the transition from military to civilian life (Higate, 2001; Karner, 1998). These studies revealed that the military has particularly significant social space in terms of the 
This is an author-produced, peer-reviewed version of this article. The final, definitive version of this document can be found online at Gender, Work, \& Organization, published by John Wiley \& Sons, Ltd. Copyright restrictions may apply. doi: 10.1111/gwao.12358

inculcation of masculinity (Abraham et al., 2017; Sayer et al., 2009; Woodward \& Neil Jenkings, 2011). For example, Karner (1998) made linkages between military masculinity and its relation to domestic violence through the studies of Vietnam veterans with PTSD.

Woodward (2000) argued that there are multiple forms of military masculinity, and each military masculinity is celebrated in a different way. She also added that the warrior in our study, is strongly tied to Connell's (1995) hegemonic masculinity. Thus, studying the construction and transfer of military masculinity may lead to, if any, enactment of the hegemonic masculinity at a different context.

Our study contributes to the understanding of the construction and practice of military masculinity-as a representative form of hegemonic masculinities. We explore how military masculinity is constructed and then practiced outside of the military-at the workplace. In doing so, we demonstrate that the interface between the military and workplace as gendered social arenas illuminates how different social fields function as facilitators and reinforcers of masculinities.

\section{Theoretical Framing: Bourdieu's Theory of Practice}

Our study is informed by Bourdieu's (1977) Theory of Practice, which requires the incorporated understanding of practice as the interplay among habitus, capitals, and fields (e.g., Abraham, Cheney, \& Curran, 2017; Spence, Carter, Husillos, \& Archel, 2017). To unravel the linkage between military masculinity and its construction and practice in the workplace, one must understand how men internalize a particular set of values and norms in a certain social space, and what practices are enacted as the results of the process (Gherardi, 2009). Through his theory, Bourdieu $(1977,1990)$ illustrates how social structures and individual agencies are reconciled, and reciprocally shape each other. Bourdieu's framework was not originally adopted in our study, and did not guide our research questions, but this framework emerged while analyzing our data. We present it in this section for clarity of reading.

The first element of Bourdieu's theory (1977) is habitus. Habitus refers to "a set of durable and transposable dispositions, an embodied history internalized as a 'second nature"' (Bourdieu, 1990, p. 56) of agents comprising a "structured and structuring structure" (Bourdieu, 1984, p. 170). Habitus is "structured" by the historical and present circumstances of agents and, at the same time, it "structures" agents present and future practices. Habitus is a set of embodied, socially constructed dispositions (Abraham et al., 2017) which directs our thought and behaviors, and shapes tastes. In so doing, habitus operates as the principle for the logic of selection (Bourdieu, 1984) because individuals with the same habitus share similar tastes of cultures, so they make a similar judgment to an object in a circumstance.

Bourdieu (1990) also claimed the notion of capital and fields. He equated social life with a competitive game (e.g., football) played in "boundaries" social fields where "interactions, transactions and events occurred (Bourdieu, 2005, p. 148). Every social agent uses various strategies to maintain or improve their social position, or social class by the accumulation of capitals at stake. Bourdieu suggested four forms of capital: economic (e.g., monetary); cultural (e.g., taste, aesthetic and cultural preferences); social (e.g., relational network with people) and symbolic (e.g., honor, recognition, credentials or image of leader). Individuals with more types and amounts of capital have an advantage over those who do not possess these types of capital, and this results in societal inequities.

Bourdieu (1977) emphasized that habitus can be an embodied cultural capital, which is sustained and transposable beyond the field (Thompson, 2008). Bourdieu contended that individuals who share the same habitus establish reciprocal and amicable relationships because they have similar taste or level of culture. Thus, lower-class individuals have difficulty entering the upper-class unless they understand and comply with its habitus. Therefore, habitus is one of the underlying mechanisms creating and perpetuating the structured power imbalances in society by making distinctions among social classes (Bourdieu, 1984).

As Knights and Willmott (1985) argued, power is a central element of the gender and organizational studies. Kimmel (1993) also contended that construction of gender cannot be spoken without its relation to power. Masculinity is performed, and the performativity of masculinity reciprocally shapes men's position as a dominant group at work (Knights, 2015; Knights \& Tullberg, 2012). In our study, masculinity is connected to Bourdieu's theory of practice. As Bourdieu argued, individual agency is the subject of the power 
This is an author-produced, peer-reviewed version of this article. The final, definitive version of this document can be found online at Gender, Work, \& Organization, published by John Wiley \& Sons, Ltd. Copyright restrictions may apply. doi: 10.1111/gwao.12358

embedded in structured social spaces-fields (Abraham et al., 2017; Bourdieu, 2005). The structured spaces, for example, the military, inhabited by both agents and institutions, delineating social classes. In a field, habitus, as a system of embodied dispositions, is constructed through engagement in practice (Abraham et al., 2017). Masculinity is a habitus shared by a hegemonic group of men (McNay, 1999). Thus, it acts as a favored norm or behavioral protocol of dominant class at work. Individuals who want to gain more power and ascend the organizational hierarchy, therefore, should be encouraged to embody the hegemonic masculinity as a habitus. In this sense, the masculinity reinforces the power gap between social class (Bourdieu, 1984, 1990). The perpetuating imbalance between the power and social status is arisen depending on the possession of a habitus. In the same vein, masculinity as a habitus is represented through gendered behaviors, which is shaped, learned, legitimized and encouraged by the various structured social fields.

Criticizing limitations of reflexivity dependencies in the previous gender identity literature, McNay (1999) calls for attention on the human body as the locus of an embodiment of gender identity. McNay (1999) suggests that Bourdieu's notion of habitus and field yields a more suitable explanation for masculinities as embodied practice than feminist or Foucauldian ideas. Given that the theory of practice premises the durable and transposable nature of habitus (Bourdieu, 1977, 1990), we found Bourdieu's theory to fit our findings since we focused on the mobility of masculinity practices and the connection among social contexts.

\section{Context of the Study: Military Masculinity in South Korea}

We conducted this study in the Korean cultural context. Militarism is a major part of Korean culture (Cho et al., 2016; Lee, Chung, Lee, \& Seol, 2002) as is hegemonic masculinity (Cho et al., 2016; Kim, 2006; Won, 2016). Military service has been mandatory to all South Korean men since 1945 upon the division of North and South Korea (Chung, 2008). From 1960s to early 1990s, the nation's economic growth dramatically increased by military-led industrialization, and militarism has seeped into many fields of Korean society including corporate sectors, athletic fields, and even academia (Gwon \& Lee, 2011; Lee et al., 2002; Nah, 2005). Through this time, Korean employees had been considered as "warriors" (Kearney, 1991) and the military culture socializes Korean men into the norms and values of masculinity (e.g., Arkin \& Dobrofsky, 1978; Barrett, 1996). For example, a rank-and-file employee in the Korean workplace confesses that he cannot talk back or reject the order of his team leader, equate the leader with a military commander (Song, 2007).

Studies on military masculinity in Korea have focused on the how the military masculinity is enacted and gender binary which continues to polarize relationship between genders by subordinating, marginalizing, or undermining women with respect to men (Knights \& Kerfoot, 2004). Nah (2005) found the influence of militarism of veteran male students. Physical and psychological violence is a major vehicle of maintaining hierarchical order among male students and the military culture drove men to view female students as sexual objects. Lee (2005) also focused on exploring how the military experience forms masculinity and power, separates themselves from women, and builds militaristic and hegemonic masculinity in college. More recently, Cho et al. (2016) revealed how women leaders perceived difficulties in leadership development, and work-life balance in the militaristic workplace culture. Their studies uncovered the challenging situations women encounter such as forced drinking together, limited networking, or lack of developmental opportunities.

Completing military service in Korea is not merely a rite of passage for men but also a vehicle for social mobility. For example, in Korea, veteran status is considered as an indispensable prerequisite for or highly preferred qualifications by the corporate sector (Song, 2017) albeit the irrelevancy between the militaryrelated knowledge or skills and the prospected career. Therefore, we assume that there can be a linkage between the military experience of Korean men and workplace masculinity in Korea (Lee et al., 2002; Nah, 2007) and the previous discourse on the multiplicity of military masculinities (Woodward, 2000), in that the influence of military is not limited to the gender binary. It also allows veterans more privileged status over other men. 
Our understanding of how the military masculinity of men is capitalized and practiced across the different fields is still veiled. A study grounded in men's experiences across multiple life-stages is needed to understand how the construction and practice of military masculinity inside and outside of the military.

\section{Methods}

Grounded theory is the primary methodology fitting our research purpose. Grounded theory has been used to study identity and identity changes among different populations and contexts (e.g., Corley \& Gioia, 2004; Pratt, Rockmann, \& Kaufmann, 2006). This method allows relevant constructs to emerge from participants' accounts of their experiences and this method provides space for the specific Korean context. Grounded theory methodology is particularly useful for addressing "questions about process" or "how something changes over time" (Merriam \& Tisdell, 2016, p. 43).

\section{Participants}

Twenty Korean men who had completed the two-year mandatory military service and worked as full-time professionals participated in this study. Participants' age ranged from 28 to 35 years old (average age of 32.5 years). All participants held at least a bachelor's degree, which is required for full-time employment in professional positions at Korean large corporations. We chose these criteria because men with these credentials follow the similar life trajectory of attending college, completing military service, returning to college and entering the workforce. The characteristics of the sample are shared by a large majority of Korean men (in 2017, the average age of Korean men was 26 years old and $76 \%$ of Korean men had a bachelor's degree; Incruit, 2017; Statistics Korea, 2017).

Although we focus on a particular group of Korean men, we believe that they can be representatives of a dominant social class in a certain culture where hegemonic military masculinity is favored as a symbol of an ideal man or a good citizen. More specifically, our participants have the attributable characteristics of the privileged group of society represented as majority ethnic male group with high-level of cultural capital (i.e., education and veteran status), economic capital (i.e., professional in the large firms) and social capital (i.e., networking with other dominant class) (Bourdieu,1986; 1990).

Our participants had two to eight years of work experience (average tenure of 5.8 years). The participants worked in the top large Korean corporations (more than at least 500 employees) from a wide range of industries including information technology, construction, automobile manufacturing, pharmaceuticals, and insurance. Most participants were assistant managers or recently promoted to managers (17 participants). The "young blood" or the new employees typically hold the assistant manager and manager positions. To protect the identities of participants we assigned pseudonyms (see Table 1).

[Insert Table 1 about here]

\section{Procedure}

Data Collection. We employed criterion and snowball sampling techniques (Patton, 2000). We invited Korean men who (1) held a veteran status (i.e., served in the military as soldiers or on active duty), and (2) worked in a large Korean corporation for less than 10 years. We sought participants with less than 10 years of work experience, so they would have a relatively fresh memory of their military service experience.

We used our personal and professional contacts to begin the data collection. The first author conducted the interviews via Skype using a semi-structured interview protocol. The interview questions addressed participants' definition of masculinity (e.g., "What do you think about the being a man in Korean culture?"), the military experience (e.g., "Tell me about your military experience."), and changes in masculinity after the military experience (e.g., "How would you describe being a man? Has your image of an ideal man has changed?") and the impact of the military experience on participants (e.g., "How would you describe the impact of serving the military on you?"). Interviews lasted 60 to 90 minutes. The average interview length was 60.8 minutes. Interviews were audio recorded and transcribed verbatim yielding 339 pages of transcript 
This is an author-produced, peer-reviewed version of this article. The final, definitive version of this document can be found online at Gender, Work, \& Organization, published by John Wiley \& Sons, Ltd. Copyright restrictions may apply. doi: $10.1111 / g$ wao. 12358

data. Each participant received a copy of his interview transcript to confirm the accuracy of content and make changes or comment as needed. Most of our interviewees confirmed the transcript's content, three made minor edits to the content, and only one participant removed two sentences from his transcript.

We conducted three pilot interviews (two veteran soldiers and one commissioned officer) to gain an initial understanding of the participants' experiences and test our interview questions. From the pilot interviews, we learned that going back to college after completing military service has a distinctive role in participants' masculinity construction. We modified our questions to reflect our new understanding and capture the impact of college on militaristic identity change. Further, we narrowed the target population to veteran Korean men who served soldiers, as opposed to commissioned officers, because soldiers enter corporations to pursue their careers upon completing the mandatory Korean military service. Commissioned officers pursue careers within the military so they may not represent the identity change that veteran Korean men experience.

Data Analysis. In this study, we used grounded theory for our data analysis (Strauss \& Corbin, 1990). We borrowed Gioia et al.'s (2012) approach to "new concept development and grounded theory articulation" (p. 15) to the conduct and presentation of the data analysis. Gioia et al.'s (2012) method involves first-order coding, second-order categorizing, and aggregated categories identification. The first-order coding involves descriptive interpretations of the data, in which we created first-order categories (Gioia et al., 2012). Therefore, the first author-as the lead on the data analysis-thoroughly read each interview transcript and coded it line-by-line and then constantly compared the codes and merged them into initial or first-order categories. This process yielded 18 initial categories that were later combined into eight second-order categories.

For the second stage of coding, we created second-order categories (Gioia et al., 2012) moving toward a more theoretical understanding of our data. At this stage we referred to the existing literature multiple times and through an iterative process of examining our data and the literature, we finalized the second-order categories. For example, informed by Bourdieu's theory of practice, we conceptualized participants' descriptions of their attempts to imitate the leadership behaviors they learned during military service in the workplace as 'practicing the military masculinity.' We borrowed the concept of practicing from Bourdieu's theory of practice to label this category.

Using the Gioia et al.'s (2012) method, we identified 'aggregate categories.' Looking at the second-order categories, we concluded that they all reflected four fields where military masculinity is constructed, transferred and practiced (Figure 1). This process involved further iteration between the existing literature and the identified categories. The iterative process was facilitated by frequent meetings of authors to discuss and reach consensus on labeling categories. In a few cases, authors' discussions led to re-labeling categories. For example, the category "embodied military masculinity as a new habitus" was previously labeled as "imprinted militaristic masculinity as lived experience". Finally, as shown in Figure 2, we created a model that connects all the categories. As Gioia et al. (2012) put it, our model is "grounded in the data (as exemplified by the data structure), one that captures the informants' experience in theoretical terms" ( $p$. 22).

Trustworthiness. We used two strategies to ensure the credibility of our findings. First, we used a peer debriefing technique (Lincoln \& Guba, 1985). We asked two colleagues knowledgeable about qualitative research methodology to examine and verify the relationships between the categories as placed in our model. Second, we reflected on our potential influence as researchers throughout the study. Recognizing that the methods used in grounded theory research are shaped by the researcher's position (Birks \& Mills, 2011), we identified our epistemological positions as constructivists' who believe in multiple subjective realities in contrast to one single objective reality (Crotty, 1998). Our research team involved one Korean man and two Korean women who knew the Korean military and corporate culture. The lead author is a Korean veteran who had completed the military and worked for a large corporation, thus relating to the participants' experiences and understanding their decisions and perceptions. Our Korean team members provided an emic perspective. However, our research team also involves two non- Korean members who provided outsider perspectives complementing those of our Korean members.

[Insert Figure 1 about here] 


\section{Findings}

Informed by Bourdieu's theory (1986; 1990), we constructed a model that shows the process of military masculinization and capitalization (See Figure 2). Our analysis shows that our participants' masculinities changed across four different social fields. The conception of the masculinity started with raw and unsophisticated images of manhood and evolved into institutionalized and more tailored images of warriors in suits, the dominant class of men who share the habitus acquired from the military experience, but who hide this masculinity through more socially acceptable behavior. , These men have more cultural capital and power than women and men who are non-veterans. The military masculinity is then enacted at the workplace and is a factor in perpetuating gender inequality. First, our participants had an immature image of masculinity during early college years (before serving in the military) that included a real man as being physically strong, having a wild personality and being popular (see Phase 1 ). When participants entered the military, they encountered the military's hierarchical system, learned compliance as a core value, and acquired military masculinity as a new identity (see Phase 2). Coming back to college with veteran status, participants practiced the newly acquired military masculinity by applying the habitus to their younger men peers (see Phase 3). Finally, participants established a new sense of the military masculinity in the workplace (see Phase 4). We provide detailed explanations of each phase with representative quotes from our participants in the following sections.

[Insert Figure 2 about here]

\section{Phase 1: Pursuing Raw Masculinity Before the Military}

Our participants' construction of military masculinity started in college when they encountered veterans. During the college years, participants pursued a raw image of masculinity and exhibited ambivalent feelings toward the militaristic culture of the college.

Pursuing a Raw Image of Masculinity. All participants reported that their conceptualizations of masculinity before military service were closely related to physical strength and appearance. Participants described a real man as "a strong man," "a sports guy," "a show-off," "someone with a muscular body," and "someone with an outgoing personality." These relatively primitive and unsophisticated images of manhood were attractive to the participants in their early college years because they thought such masculinity appealed to their friends and women. Macho, "alpha male" behavior was considered masculine. For example, participant M15 recalled his image of manhood during his freshmen year as a "macho" man, "a loud person who enjoyed playing soccer, drank a lot of alcohol and was easily involved in fights." Another characteristic of the raw image of masculinity was resistance to the existing order. During their college years, participants tried something defiant to show their "power" off to their peers. Such defiance can be interpreted as the mental equivalent of physical strength.

Having Ambivalent Feelings Toward the Militaristic Behaviors. Before they have not entered the military yet, our participants recalled that they resisted and disliked the veteran students' behaviors. Veteran students typically took a two-year leave to serve in the military, and when they returned to college, they brought this military culture with them. The veteran students pushed the non-veteran students to respect "the higher rank" of students and to be respectful toward older students; the following quotes represent the negative feelings the participants expressed towards the militaristic behaviors the veteran students brought to the college:

For me, the veteran students looked like professional soldiers...they were rigid, stubborn. I did not understand why they emphasized showing so much respect for elders. (M13) You may know, in the MT [membership training, orientation camps for freshmen in Korea], veterans forced us to do some disciplinary actions in a military-way, shouting 'Hit the dirt!' or they even kicked us. I thought it was crazy. (M3)

Conversely, non-veteran students also referred to positive feelings toward veteran students. They saw veterans as "mature grown-ups." The participants' comments typified others: 
I felt like veteran students were grown-ups and viewed them as adults. They were just young students aging 23 or 24 . However, looking back at those times, I perceived the veteran students as much more mature because they knew a lot, led student team projects and delegated the tasks very well. They looked like real men being intelligent and excellent problem solvers. [M9]

Thus, college as the first social field functioned as a stage where non-veteran and younger students encountered the military masculinity, which imprinted an image of veterans as mature men in their mind. Our participants' masculinities or habitus was not hegemonic or fully established at this stage. However, the clash between the two male groups functioned as 'a reference' later when they become veterans.

\section{Phase 2: Constructing Military Masculinity as a New Habitus}

During military service, our participants learned the militaristic values and internalized the behavioral protocols of being a man in the military. The two-year military service as the second social field provided an intense socialization process, which "imprinted" the military masculinity in minds and bodies of our participants. For our participants, the construction of military masculinity starts with taking the role of a soldier and complying to the hierarchical order of a system, and it finally becomes a habitus as an organizational man.

Internalizing the Militaristic Compliance Through the Military Experience. All our participants served as soldiers, the lowest rank in the military. Participants described their military service experiences as "the first experience of a strict hierarchy" (M2). As soldiers, participants had to take superiors' (e.g., commanders) orders unconditionally and they had to value being part of a collective and hierarchical system. Through the military training and life in barracks, participants gradually internalized militaristic compliance as their central value in building military masculinity.

"SSKK (Si Ki myun Si Ki nen dae ro, KKa ra myun KKa ra nen dae ro)", a slang, which translated verbatim means, "Do what you are ordered, even if it is to peel a chestnut burr with your penis," reflects the brutal experience of accepting orders unconditionally in Korean military. SSKK is engraved in soldiers' minds and bodies throughout the military socialization. Participant M1 said, "In the military, there was a culture that you were not allowed to have your own idea. You have to do exactly what you are ordered...no more, no less. Especially when you are in a lower rank." Participants also mentioned that taking unconditional acceptance of orders was forced on them through violence. Participant M18 commented that "Everyone used violence.....and things considered as abnormal can be normal in the military. Nobody could resist it." Furthermore, SSKK's oppressive culture affected the soldiers in a way that they learned submissive behaviors as the bottom of the hierarchy in the military. This process significantly influenced soldiers' obedience to authority and turned them into compliant men. One participant said:

I lived the experience of accepting things I saw and heard, which I didn't understand in my college life before the military. It's not like something I learned through a curriculum. Seeping into my body, I was gradually colored by it. (M13)

The lived experience of the hierarchical culture of the military affected the participants' masculinity. They slowly recognized themselves as part of the hierarchical system. They learned that the organization had a goal, and they had to contribute to achieving that goal. One participant said, "WE needed to be successful as a group" (M15). In this process, participants' initial (pre-military raw) masculinity was transformed into being part of a system which was considered necessary and even virtuous as a man. One of our participants said, "Manhood is more than just appearance - when you contribute to the goal of the organization as part of a group, it means being a real man" (M8)

Separation from the Previous Image and Pursuit of Agentic Behaviors. Participants transitioned from the pre-military raw masculinity (Phase 1 ) and found a new image of the ideal man through the military experience. As participants spent more time in the military context and matured, they regarded the raw masculinity they previously aspired to as something to avoid and saw individual-oriented and defiant behaviors as taboos. One participant commented: 
This is an author-produced, peer-reviewed version of this article. The final, definitive version of this document can be found online at Gender, Work, \& Organization, published by John Wiley \& Sons, Ltd. Copyright restrictions may apply. doi: 10.1111/gwao.12358

When I saw those who [nonveterans] didn't comply with given rules, I realized I also acted that way with such a demeanor before my military service... following the military, I developed the maturity to cater to my elders and silently comply with instructions. (M5)

In addition to detaching from the old concept of masculinity, participants adopted a new masculinity that was closely related to an image of "capable," "responsible," "tolerant" and "self-reliant" leader.

Participants started to see that an ideal man is a man "in the suit" who looks smart and is capable. "You need to be a leader and follower at the same time; you need to catch the superior's orders and translate the orders into your subordinate" (M7). Such experience of responsibility and leadership inspired the conceptions of the new masculinity. One participant said:

I tried to act like a responsible leader. My subordinate made a mistake; I reported to the lieutenant that "I will take care of this," instead of blaming [a subordinate]. Staying up all night, we solved the problem together because he was my person. (M15)

One participant added:

To me, a real man is a leader. I cannot separate a man from a leader. Masculinity is leadership. A real man should take care of his subordinates. For example, I allowed my subordinates [private soldiers] to read books or use vending machines. And I gave my leave so my subordinate soldiers could take it, and volunteered for the patrol missions for my people. (M17)

In conclusion, in the military as the third social field, our participants disengaged from the previous masculinity they had and started to adopt the military masculinity as their new and ideal image of manhood. The military provided iron discipline, team-based training and life, and new role models, which influenced our participants' habitus, a system of dispositions. In particular, the transition from the individual-centered self to the group-oriented self occurs based on the militaristic compliance which is imprinted and embodied by experiencing the hierarchical and collective system of the military, from the private soldier rank (bottom) to the sergeant rank (top). They also pursue agentic behaviors as the attributes of an ideal man. Armed with the newly constructed masculinity, they marched to college.

\section{Phase 3: Incubated Military Masculinity}

Phase 3 was characterized by the liminal status of masculinity where individuals move to a new masculinity and they practice it outside of the military. This phase happened after the participants were discharged from the military with the veteran status and came back to college to complete their bachelor's degrees. At this point, participants' masculinity had changed from the pre-military raw masculinity to the new militaristic masculinity. As an objective institution, the college was still the same place where veterans and nonveterans met. However, from the veterans' view, the college was the third social field where veteran students practiced their newly acquired military masculinity before they entered the world of work. When they re-entered college, the veteran students expected to be a dominant group that led that leads women or less dominant ment (i.e. non-veteran or younger students). The college, I a microcosm of society, provided both encouragement and resistance (from female and non-veterans) toward their military masculinity, and ultimately taught them how to subordinate women and other men. Interestingly, this process was structural, so the veterans "had to be leaders," even when they did not want to be. Through these experiences, they saw being the ideal man and having good citizenship as the best way to portray their masculinity.

Practicing the Militaristic Masculinity. When our participants re-entered college, they saw structural similarities between the military and college contexts. Participants felt that other students, as well as their professors, expected them to act as leaders.

Participants noted that "the hierarchical culture of college resembles the military." Thus, "certain orders are necessary to maintain the organization." There are strong bonds among cohorts, and students are connected to each other based on the hierarchical order. Hakbun, a number representing the class year, is 
regarded as a symbol of seniority and it has the same function as ranks in the military. As veterans, our participants felt a sense of obligation to assume leadership in group projects in class or leading boot camps for freshmen students. Participants remembered that when they were a freshman, the veteran students acted the same way. Veterans behaved according to the hierarchy, took leader positions, and imposed specific behavior protocols and proper manners in communication with older students. At the same time, they also took initiatives in doing harder or difficult tasks. They positioned themselves as mediators, managers, and supporters of the department. Consequently, different from the pre-military masculinity, participants exhibited more agentic, group-based behaviors and tried to maintain order in the department to which they were affiliated. One respondent stated, "I thought I should definitely be the leader because I am a man, senior, and veteran. I didn't want to lead, but I should do so." (M9)

Tailoring the Military Masculinity. Although our participants performed based on the military masculinity, they were ambivalent about their own behaviors. They knew their military masculinity could be seen negatively so they tailored their military masculinity to be more acceptable; they "did not want to be seen as soldiers" (M17). This tailoring process did not mean they saw men and women as equal. Rather, participants subtly adjusted their military masculinity to fit the civilian context. One participant stated:

In the beginning, perhaps I still hadn't taken off my military clothing? I translated military ranking into the school seniority system. "How dare you just sit around when I am cleaning our club room?" but then later...I thought "Oh, this is a school, not the military." (M3)

Another participant added:

It was hard for me to adapt to the college life [after coming back from the military]. I was a bit frustrated. I had the highest rank in the military [a sergeant,] but not at school, the situation had changed. The [non-veteran] students used a different language. It was hard to communicate. So I tried...I tried to use the ordinary language [that they used], not to curse. Because cursing is the ordinary language in the military but not in the society. If someone asked you a question which you don't know, you might say 'I don't know', but in the military, you have to say 'I will figure it out, sir.' (M17)

Tailoring also includes positive, agentic behaviors such as "staying emotionally stable or being rational", "well-informed," or "willingly taking hard or difficult tasks." Thus, the negative aspects of their military masculinity are jettisoned and the rest is maintained as an ideal man's attributes. These behaviors are then encouraged, reinforced, and reproduced through interactions with other students and faculty. Consequently, through the "incubating" processes of practicing, adjusting, revising and confirming their military masculinity in the college, they are prepared to enter into a society where the hegemonic masculinity is still considered desirable.

\section{Phase 4: Capitalization of Military Masculinity at Work and Becoming Warriors in Suits}

Our participants applied a more refined military masculinity to their workplaces. The application of military masculinity was exhibited in two ways. First, military masculinity operated as a habitus. Militaristic compliance set our participants' behavioral standards or habitus. Based on the military masculinity protocol, participants strategically utilized the agentic behaviors to locate themselves in the organizational hierarchy. Second, as a form of habitus, military masculinity gave them a way to judge others as veterans or nonveterans, and rationalize their evaluation based on their habitus.

Military masculinity was valued at work. The military masculinity was enacted, confirmed and ultimately become a cultural capital which contributed to the veterans' dominant class, subordinating other femininities and masculinities at work.

Transferring and Legitimizing Military Masculinity at Work. By this point, the military masculinity had become a habitus and manifested in how they behaved in a certain way in the workplace. As new employees, participants saw similarities between the military and the workplace. One participant noted: 
It's a legacy, thinking 'We, not l' in [South] Korea, even though you don't want to...the twoyear experience [of the military service] is the time when I lived as one of the soldiers, not myself. The company is the same. I need to finish my job as a member of the company with a certain rank. (M11)

Because participants saw structural and cultural similarities between the Korean military and workplace, and also practiced the militaristic compliance during the college years, they skillfully transferred the behavioral protocols they embodied in the military and college to the workplace. All participants said they acted like a private soldier when they were newcomers. Participants communicated with supervisors in the same way as they did with their superiors in the military. They took hard tasks, even unreasonable orders, and never said "No" to their supervisors even if they thought the task was absurd. One of the participants said:

Sometimes nonsensical tasks are given. For example, something not on my job description or impossible to meet the due date, but I simply say 'Yes' to my boss, no grumbling. Then I think about how to make it. I take the task to my subordinates and try to persuade them to get it done (M2)

A second participant added:

What I learned from the military definitely helped me when I was a newbie. Although I am a man, making coffee for my supervisor can be a way to show manhood. This is a strategy I learned in the military. Like private soldiers polish the sergeants' shoes. In the same way, giving what seniors need in advance makes a good impression. (M8)

Participants who were promoted to assistant managers or managers, considered militaristic compliance as a "necessary evil" (M7) to manage and accomplish larger tasks. Surprisingly, even participants who had negative attitudes toward the military experience admitted that the militaristic compliance is necessary for the Korean workplace. One of our participants had a strongly positive opinion about militaristic compliance. He claimed that this is part of the Korean culture to be harmonious with other people in the workplace of Korea; one must understand and possess militaristic compliance. He said:

I think SSKK is somewhat needed in the workplace. Because we have the conscription policy, most Korean men serve the military. So, yes, I think that [SSKK] is part of our culture and the protocol for our behaviors. When we hire a person in Korea, basically the one who understands the military culture is favored. (M7)

Exhibition of military masculinity and compliance as habitus gave them a reputation as good employees from their superiors who also share the same habitus. Furthermore, through this process, the military masculinity finally is transformed to a cultural capital representing attributes of "a good worker" and leads them to belong the dominant class - heterosexual Korean veteran men - of the workplace.

Making Distinctions Between Co-Workers Based on the Militaristic Compliance. Our participants considered their veteran colleagues as their allies because of the shared habitus- militaristic compliance. The participants described nonveterans as relatively "uncooperative and incompetent." Those who shared the military experience formed strong bonds with each other at work. A participant stated:

If you want to work in Korea, you should serve in the military. Because everyone has that experience, it can be a good source of conversation or closer relationship with other men [at work]. Most importantly, having military experience gives you an idea of how organizations work...it's intuition. (M1)

In addition, with the militaristic compliance as a form of habitus, participants felt more comfortable working with other veterans and believed that they could rely on them because they understood compliance and making sacrifices for organizational goals. The following quote reflects this preference to work with veterans: 
Working with [veteran] men is more comfortable. They think in the manner same as soldiers. When we have unexpected, overtime working situations, or when I scold them for their mistakes, they accept it more easily and do not take it personally. Unlike veteran colleagues, women are sensitive, resistant, and less compliant. They [women] even cry at work. (M6)

Study participants thought less of those who did not fulfill their military service on active duty. They believed that any other status implied that the person may have psychological or physical problems. Those who completed service in an alternative form such as serving in the defense industry or doing public service was seen as less competent. Non-veterans were seen as lacking leadership or initiative and women were seen as not willing to make sacrifices for the organization compared to veterans.

Participants resoundingly indicated they preferred to work with other veterans as their first choice. Nonveterans were least preferred. Our participants positively assessed women who exhibited the militaristic habitus with compliant and agentic behaviors and had more negative perspectives toward nonveterans. For them, therefore, the shared habitus is a more crucial yardstick to evaluate others than gender.

Non-veterans are trouble-makers. They don't have the so-called "sense." When drinking together, they just sit around the corner fiddling with cell phones. Yes, it is hard to generalize, but they are the examples... and we think they are pathetic. They cannot stand if a situation goes wrong. They talk back to their supervisors; they think they are special. (M7)

Meanwhile, one participant asserted:

I rather choose women [instead of nonveterans] because, some women have their own strengths, like working more carefully and precisely. Also, they tried to do the same things with men... like working overtime or drinking much alcohol. This signals me this woman at least makes an effort, or sometimes, they work better than men. (M4)

To our participants, the workplace provided a social field where the veterans' masculinity was regarded as the desired image of an organizational member. The military masculinity, or a habitus, was then used as a cultural capital in the organizational context. Our participants differentiated themselves from women and other "inferior men," who did not exhibit the same habitus. Through the legitimization and capitalization of their military masculinity, veterans become warriors in suits. These warriors in suits are the dominant male group in Korean workplace who have secured a hegemonic, privileged status, and power over women and other men based on their habitus. Although warriors in suits live and work in a civilian context, their ways of thinking and behaviors are deeply rooted in the habitus shaped through the military experience.

\section{Discussion}

The overarching purpose of this study was to explore the impact of men's military experiences on the construction of masculinity and how the constructed military masculinity is practiced, legitimized, and capitalized in the workplace as a perpetuating mechanism of discrimination and power imbalance. To answer our research questions, we conducted a qualitative inquiry on Korean men's lived experiences. Interviews with the 20 Korean young men who completed the obligatory military service and currently hold a professional career incorporates show us the construction and practice of masculinity of Korean men across the multiple social fields.

The present study contributes to the literature by expanding the understanding of masculinity construction and mobility across social fields. First, our study adds new insights to masculinity literature, in that how the structural characteristics of social fields contribute to the abiding regime of hegemonic masculinity through its construction, practice, and capitalization at work. Connell (1995) asserted, "Hegemony is likely to be established only if there is some correspondence between cultural ideal and institutional power" (p. 77). Applied to our study, the socially legitimized men's image, or a habitus, functioned as a cultural capital and granted men a privileged, dominant position in the workplaces, and justified their dominance and power inequalities in the organizational hierarchy. 
We propose a four-phase model that illustrates the process of construction and practice of military masculinity across multiple social fields. Our Korean participants start their masculinity construction by encountering the militaristic masculinity of veteran students in college, which provides them with indirect military experiences. Although they initially have a rebellious attitude toward the veterans' forceful behaviors, they also perceive the veterans' behaviors as attributes of more mature, competent and leading man. In the military, they detach the machoism from their pre-military conception of ideal manhood and the military masculinity is embodied as a habitus through the military socialization. After they are discharged from the military, they practice and tailor their newly acquired masculinity through the interactions with people in college, and confirm that this way of expressing masculinity works. In this way, the military masculinity can be incubated. Finally, Korean men exert their hegemonic military masculinity at work to acquire more cultural capital and share their habitus with veteran employees. Based on military masculinity as a habitus, they define themselves as an ideal worker and make a distinction between those who show the same habitus and those who do not. In sum, our model shows how serving in the military for two years leaves a legacy on masculinity during the college years and in the workplace.

The masculinity as habitus (i.e., agentic behavior and compliance) functions as a significant capital across the fields of college, military and workplace, which gives them more competitive positions within the fields (Bourdieu, 1977, 1990). Korean men exhibit agentic behaviors, and those behaviors are favored in many subfields of society. This embodied masculine behaviors, in turn, is used to judge others behaviors and legitimize veteran men's habitus. In so doing, the capitalized masculinity helps them to hold a prominent position at work.

Our analysis, which looks at the construction of masculinity before college, in the military, after military service but before entering the workforce, and in the workforce gives us a much more holistic picture that has been presented in the literature. The extant literature on hegemonic or military masculinity has focused on either inside or outside of military (e.g., Abraham et al., 2017; Hale, 2008; Sasson-Levy, 2003) or has focused on military masculinity as it regards Post Traumatic Stress Disorder (PTSD) (Karner, 1998). Hegemonic masculinity affects workplaces (lacuone, 2005; Mumby,1998) and our study adds depth to the extant literature as it looks how it is formed an enacted across contexts.

By pointing to the structural influences of fields on masculinity, our study calls for a more macro-level understanding of masculinities, especially for deconstructing gender binary (Knights and Kerfoot, 2004). We especially urge researchers to explore the interface between fields (e.g., military to school or workplace) where hegemonic masculinities are mobilized, encouraged and practiced under the favor of institutionalized or cultural forces. Intervening to this interface may be critical to deconstructing the perpetuating gender inequalities and power imbalance in organization and society.

Our second major contribution to the literature is showing that men more subtly manifest their masculinities depending on the characteristics of a field where they are situated. Traditionally, military masculinity has been closely aligned with the discernible constituents such as a muscular body, aggressiveness, emotional control and physical violence (e.g., Higate, 2007; Woodward, 2000; Woodward \& Neil Jenkings, 2011). Celebrating these traditional images of military masculinity, however, did not surface in our findings. Instead, our participants tried to disguise their military masculinity in a more socially desirable form while maintaining the core elements of masculinity as a habitus. Consequently, they interact with the social norms, values, and strategically adjust their masculinity. Perhaps this is because of the recent proliferation of feminism or heightened awareness of gender equality in society. However, our analysis reveals that hegemonic masculinity is hidden under more socially appropriate behavior. The metaphor "warrior in suits" thus represents 'the hegemonic masculinity undercover.'

Our findings confirmed that dominant masculinity is not innate, but acquired through varied experiences such as training, socialization or education as a form of habitus (Bourdieu, 1984, 1990). Because our participants endured the harsh environment and intense training in the military, they rationalize their superior status over women and other men, as men. Through sharing and reinforcing their military masculinity as a habitus, and excluding other inferior groups (i.e., women and non-veteran men), they secured their dominant position. 
This is an author-produced, peer-reviewed version of this article. The final, definitive version of this document can be found online at Gender, Work, \& Organization, published by John Wiley \& Sons, Ltd. Copyright restrictions may apply. doi: 10.1111/gwao.12358

As our third contribution to the literature, we extend the discourse of doing gender or masculinity as an embodied practice in relation to Bourdieu's theory of practice. The binary classification of doing gender assumes that men and women act out their gender in stereotypical ways (Deutsch, 2007; Martin, 2001). However, using our Bourdieusian (1990) perspective on doing gender or practicing masculinity, we see the influence of power, class relations, and habitus on the enactment of masculinity. Based on their militaristic habitus, our participants strategically utilized agentic and compliant behaviors to create their images as "ideal workers" who understood and internalized organizational norms. While Martin $(2001,2003)$ found that men unreflexively mobilize masculinities which are pertaining to their sex category, our findings show that Korean veterans intentionally and strategically employ their masculinities as part of their gender identity (Kerfoot \& Knights, 1985). Perhaps this is because men lower in the organizational hierarchy exert masculinity to gain more cultural capital. In this situation, veteran men's habitus directs them to use submissive behaviors to achieve better positions at work, even though the behaviors are traditionally and culturally considered "feminine" (e.g., making a coffee or cleaning the desk for the boss). By confirming the organizational hierarchies, these feminine behaviors paradoxically show how men practice military masculinity at work.

For Korean men, practicing or mobilizing masculinity is not necessarily associated with being male, but rather a spectrum from "more manly" (Gutmann, 1997) to "less manly" given the power relations and gender hierarchy. Thus, as one of our participants (M4) said, if a woman colleague displays such agentic and compliant behavior, men consider the woman as a comrade because they share the same habitus. In the same vein, when a man (usually non-veteran) does not share the same habitus and follows different protocols (e.g., talking back to the supervisor or complaining about a work), Korean men with hegemonic masculinity exclude him. In so doing, every agent in the workplace, regardless of gender, has to follow the golden rule of the game - hegemonic military masculinity - to be elevated to the dominant group. This Bourdieusian perspective on doing gender also explains why some women leaders in workplace distance themselves from other women and legitimatize gender inequality in male-dominated organizations and they are seen as "queen bees" (Derks, Van Laar, \& Ellemers, 2016). Consequently, our study confirms the argument that gender inequality is perpetuated through mobilizing masculinities (Kelan, 2018; Martin, 2001), but at the same time, reveals that there is another layer in masculinities which are resulted from the combination of gender differences and militaristic habitus.

Our findings expand the Bourdieusian notion of the field as the locus of masculinity construction and practice. Prior studies have conceptualized the military a field that elicits masculine practices by valuing embodied and enacted hegemonic masculinity (e.g., Abraham et al., 2017; Sasson-Levy, 2003). Other researchers put the workplace as the center of hegemonic masculinity (Cho et al., 2016; Mumby, 1998). According to Bourdieu (1990), each social field or its subfield is bounded and autonomous. However, Bourdieu's notion of the field has been also criticized due to the vague boundaries (Thomson, 2008). In line with this, our findings incorporate the multiple fields into one macro-level field under the name of masculinity. Thus, we argue that each social field where masculinity is constructed and practiced (e.g., college- military-workplace) should be understood as an extended, continued, and connected field rather than a set of isolated, independent, and disconnected spaces. The abstract, fluid and malleable nature of field also calls for further investigations to expand and specify the boundary in term of masculinity. The field of masculinity in our study can be extended. For example, the pre-college stage (i.e., secondary schools) or other social dimensions (i.e., domestic masculinity based on patriarchal cultures such as Confucianism or religions) can be incorporated into the macro-level field of masculinity. In so doing, we can broaden our understanding of the masculinity and society. This extended view on the masculine social field, in turn, encourages us to investigate how to demarcate the interfaces of each field (e.g., college-military) to facilitating "undoing gender" (Deutsch, 2007) by discontinuing the masculinity mobilization.

Finally, our study uniquely contributions to the indigenous theorizing of masculinity in Korea. Confucianism has been used to explain the Korean masculine culture through the lens of the dichotomous gender identity (e.g., Kee, 2008; Wong, 2016). An over-reliance on Confucianist values to understand workplace masculinity in Korea, however, disregards the impact of another distinct and prominent subculture, the military (Rowley \& Bae, 2013). Investigating veteran men's experience, we found that the military subculture of Korea operates as another fundamental mechanism to form the masculinity which puts a high value on the hierarchy and collectivistic culture in the workplace. Thus, we offer an alternative explanation of the 
masculine culture of Korea with military experience as a new lens to surface men's agentic behaviors and masculinity. Concerning this argument, we highly recommend future scholars to take the military experiences of men into consideration when exploring the masculine culture of Korean corporations.

\section{Limitations}

In this study, we focused on the case of Korean men with a specific experience-men who have served the military as soldiers on active duty, graduated from college, and worked in large corporate settings in Korea. Our findings reflect this specific experience and Korean cultural context and due to the qualitative nature of the study, our observations can inform, but cannot be generalized to other populations of workers or cultural contexts. Men with different military service experience (e.g., officers or cadets) or work experience in different types of organizations (e.g., small-medium sized firms or public organizations) were not included as our participants. As Kelan (2018) suggests, gender does not equally pertain to every circumstance. Thus, interpretations of the findings apply to Korean men who complete military service on active duty, are highly educated, and work as professionals in large corporations. Furthermore, our findings may be only applicable to country contexts with a conscription policy similar to South Korea (e.g., Iran, Finland, Israel or Taiwan) where the mandatory and temporal nature of the service may have a similar influence on masculinity. Finally, our findings apply to the hegemonic and military masculinity. We acknowledge the new images of men are emerging in Korean society (e.g., Kkonminam; Elfving-Hwang, 2011; Miyose \& Engstrom, 2015). However, our findings may not apply to the images such as Kkonminam that are relatively recent and nonveteran (Lim, 2008; Maliangkay, 2013).

\section{References}

Abraham, T., Cheney, A. M., \& Curran, G. M. (2017). A Bourdieusian analysis of US military culture ground in the mental help-seeking literature. American Journal of Men's Health, 11(5), 13581365.

Arkin, W., \& Dobrofsky, L. R. (1978). Military socialization and masculinity. Journal of Social Issues, 34(1), 151-168.

Barrett, F. J. (1996). The organizational construction of hegemonic masculinity: The case of the US Navy. Gender, Work \& Organization, 3, 129-142.

Birks, M., \& Mills, J. (2015). Grounded theory: A practical guide. London, England: Sage.

Bourdieu, P. (1977). Outline of a theory of practice. (R. Nice, Trans.). Cambridge, UK: Cambridge University Press.

Bourdieu, P. (1984). Distinction: A social critique of the judgement of taste. Cambridge, MA: Harvard University Press.

Bourdieu P. (1986). The forms of capital. In J. G. Richardson (Ed.), Handbook of theory and research for the sociology of education (pp. 241-258). Westport, CT: Greenwood.

Bourdieu, P. (1990). The logic of practice. Stanford, CA: Stanford University Press.

Bourdieu, P. (2005). The social structures of the economy. Cambridge: Polity.

Bourdieu, P., \& Wacquant, L. J. D. (1992). An invitation to reflexive sociology. Chicago, IL: The University of Chicago Press.

Cho, Y., Park, J., Ju, B., Han, S. J., Moon, H., Park, S., ... \& Park, E. (2016). Women leaders' work-life imbalance in South Korean companies: A collaborative qualitative study.

Human Resource Development Quarterly, 27(4), 461-487.

Chung, B. H. (2008). Between defector and migrant: Identities and strategies of North Koreans in South Korea. Korean Studies, 32(1), 1-27.

Collinson, D., \& Hearn, J. (1994). Naming men as men: Implications for work, organization and management. Gender, Work \& Organization, 1(1), 2-22.

Connell, R.W. (1987). Gender and power: Society, the person, and sexual politics. Stanford, CA: Stanford University Press.

Connell, R.W. (1995). Masculinities. Cambridge, UK: Polity Press.

Corley, K. G., \& Gioia, D. A. (2004). Identity ambiguity and change in the wake of a corporate spin-off. Administrative Science Quarterly, 49(2), 173-208.

Cowan, D. (2008). Military workfare: The soldier and social citizenship in Canada. Toronto, Ontario: Toronto University Press. 
This is an author-produced, peer-reviewed version of this article. The final, definitive version of this document can be found online at Gender, Work, \& Organization, published by John Wiley \& Sons, Ltd. Copyright restrictions may apply. doi: 10.1111/gwao.12358

Crotty, M. (1998). The foundations of social research: Meaning and perspective in the research process. Thousand Oaks, CA: Sage.

Derks, B., Van Laar, C., \& Ellemers, N. (2016). The queen bee phenomenon: Why women leaders distance themselves from junior women. The Leadership Quarterly, 27(3), 456-469.

Deutsch, M. F. (2007). Undoing gender. Gender \& Society, 21(1), 106-127.

Elfving-Hwang, J. (2011, November). Not So Soft After All: Kkonminam Masculinities in Contemporary South Korean Popular Culture. In 7th KSAA Biennial Conference (pp. 16-18).

Gill, L. (1997). Creating citizens, making men: The military and masculinity in Bolivia. Cultural Anthropology, 12(4), 527-550.

Gherardi, S. (2009). Introduction: The critical power of the 'practice lens'. Management Learning, 40(2), 115-128.

Goldstein, J.S. (2001). War and Gender. Cambridge, UK: Cambridge University Press

Gutmann, M. C. (1997). Trafficking in men: The anthropology of masculinity. Annual Review of Anthropology, 26(1), 385-409.

Gwon, H. S. \& Lee, J. Y. (2011). Symbolic power reproduction of physical education major students: Focusing on symbolic capital of Bourdieu`s theory. Korean Journal of Sociology of Sport, 24(3), 1-25. (in Korean)

Hale, H. C. (2008). The development of British military masculinities through symbolic resources. Culture \& Psychology, 14(3), 305-332.

Hale, H. C. (2012). The role of practice in the development of military masculinities. Gender, Work \& Organization, 19(6), 699-722.

Higate, P. (2007). Peace keepers, masculinities, and sexual exploitation. Men \& Masculinities, 10, 99119.

Hinojosa, R. (2010). Doing hegemony: Military, men, and constructing a hegemonic masculinity. The Journal of Men's Studies, 18(2), 179-194.

lacuone, D. (2005). "Real men are tough guys": Hegemonic masculinity and safety in the construction industry. The Journal of Men's Studies, 13(2), 247-266.

Incruit (2017), Survey of Average Specification of New Recruits, Retrieved from http://people.incruit.com/news/newsview.asp?newsno=3652404

Kerfoot, D., \& Knights, D. (1998). Managing masculinity in contemporary organizational life: A managerial project. Organization, 5(1), 7-26.

Kearney, R. P. (1991). The warrior worker: The challenge of the Korean way of working. London, UK: I.B. Tauris \& Co. Ltd.

Kee, T. S. (2008). Influences of Confucianism on Korean corporate culture. Asian Profile, 36 (1), 1-15.

Kim, K. H. (2006). Obstacles to the success of female journalists in Korea. Media, Culture \& Society, 28(1), 123-141.

Kimmel, M. (2000). Saving the males: The sociological implications of the Virginia Military Institute and the Citadel. Gender \& Society, 14(4), 494-516.

Kimmel, M.S. \& Messner, M.A. (2009) Men's Lives. (8th ed). Boston, MA: Allyn \& Bacon.

King, A. (2007). The existence of group cohesion in the armed forces: A response to Guy Siebold. Armed Forces \& Society, 33(4), 638-645.

Klein, U. (1999). "Our Best Boys" The gendered nature of civil-military relations in Israel. Men and Masculinities, 2(1), 47-65.

Knights, D. (2015). Binaries need to shatter for bodies to matter: Do disembodied masculinities undermine organizational ethics?. Organization, 22(2), 200-216.

Knights, D., \& Kerfoot, D. (2004). Between representations and subjectivity: Gender binaries and the politics of organizational transformation. Gender, Work \& Organization, 11(4), 430-454.

Knights, D., \& Tullberg, M. (2012). Managing masculinity/mismanaging the corporation. Organization, 19(4), 385-404.

Knights, D., \& Willmott, H. (1985). Power and identity in theory and practice. The Sociological Review, 33(1), 22-46

Lahelma, E. (2005). Finding communalities, making differences, performing masculinities: Reflections of young men on military service. Gender and Education, 17(3), 305-317.

Lee, H. K., Chung, K., Lee, J., \& Seol, D. (2002). Comparative study on the labor management style in domestic and overseas Korean companies, Korean Journal of Sociology, 36(3), 47-77. 
Lee, Y. (2005). The military experience and the formation of the male subject in Korea. The Korean Journal of Humanities and the Social Sciences,29(3), 81-108. (in Korean)

Lim, I.-S. (2008). The trend of creating atypical male images in heterosexist Korean society. Korea Journal, 48, 115-146.

Lincoln, Y. S., \& Guba, E. G. (1985). Naturalistic inquiry. Thousand Oaks: Sage.

Linstead, S., \& Pullen, A. (2006). Gender as multiplicity: Desire, displacement, difference and dispersion. Human Relations, 59, 1287-1310.

Maliangkay, R., (2013). Catering for the female gaze: the semiotics of masculinity in Korean advertising. Situations: Cultural Studies in the Asian Context, 7(1), 43-62.

Martin, P. Y. (2001). Mobilizing masculinities: Women's experiences of men at. Organization, 8(4), 587618.

Martin, P. Y. (2003). "Said and done" versus "saying and doing" gendering practices, practicing gender at work. Gender \& Society, 17(3), 342-366.

Martin, P. Y. (2006). Practising gender at work: Further thoughts on reflexivity. Gender, Work \& Organization, 13(3), 254-276.

McNay, L. (1999). Gender, habitus and the field: Pierre Bourdieu and the limits of reflexivity. Theory, Culture \& Society, 16(1), 95-117.

Merriam, S. B., \& Tisdell, E. J. (2016). Qualitative research: A guide to design and implementation. San Francisco, CA: Jossey-Bass.

Mumby, D. K. (1998). Organizing men: Power, discourse, and the social construction of masculinity (s) in the workplace. Communication Theory, 8(2), 164-183.

Nentwich, J. C., \& Kelan, E. K. (2014). Towards a topology of 'doing gender': An analysis of empirical research and its challenges. Gender, Work \& Organization, 21(2), 121-134.

Nah, Y. (2005). Militarism represented, reinforced, and learned on Korean co-ed campus. Journal of Lifelong Education, 11(4), 1-32. (in Korean)

Nah, Y. (2007). Military culture in co-ed colleges: Focusing on vocalists in music department. Journal of Korean Women's Studies, 23(1), 69-102. (in Korean)

Patton, M. Q. (2002). Qualitative evaluation and research methods. Thousand Oaks, CA: Sage.

Pullen, A., \& Simpson, R. (2009). Managing difference in feminized work: Men, otherness and social practice. Human Relations, 62, 561-587.

Pratt, M. G., Rockmann, K. W., \& Kaufmann, J. B. (2006). Constructing professional identity: The role of work and identity learning cycles in the customization of identity among medical residents. Academy of Management Journal, 49(2), 235-262.

Roper, M. \& Tosh, J., (Eds.). (1991). Manful assertions: Masculinities in Britain since 1800. London, England: Routledge

Rowley, C., \& Bae, K. S. (2013). Waves of anti-unionism in South Korea. In G. Gall, \& T. Dundon (Eds.), Global Anti-Unionism: Nature, Dynamics, Trajectories and Outcomes (pp. 207-223). London, England: Palgrave.

Sasson-Levy, O. (2003). Military, masculinity, and citizenship: Tensions and contradictions in the experience of blue-collar soldiers. Identities: Global Studies in Culture and Power, 10(3), 319345.

Sayer, N. A., Friedemann-Sanchez, G., Spoont, M., Murdock, M., Parker, L. E., Chiros, C., \& Rosenheck, R. (2009). A qualitative study of determinants of PTSD treatment initiation in veterans. Psychiatry, $72,238-255$.

Simpson, R. (2004). Masculinity at work: The experiences of men in female dominated occupations. Work, Employment \& Society, 18(2), 349-368.

Song, S. H. (2007, April 9). Military culture in Korean society. The Korea Herald, Retrieved from http://www.koreaherald.com/view.php?ud=20140409000974

Spence, C., Carter, C., Husillos, J., \& Archel, P. (2017). Taste matters: Cultural capital and elites in proximate Strategic Action Fields. Human Relations, 70, 211-236.

Statistics Korea. (2017). Social indicators in 2017, Retrieved from http://kostat.go.kr/portal/eng/pressReleases/11/1/index.board?bmode=read\&bSeq=\&aSeq=37111 4\&page $\mathrm{No}=1 \&$ rowNum=10\&navCount $=10 \&$ currPg $=\& s T a r g e t=t i t l e \& s T x t=$

Strauss, A., \& J. M. Corbin. (1990). Basics of qualitative research: Grounded theory procedures and techniques. Beverly Hills, CA: Sage. 
Thomson, P. (2008). Field. In G. Michael (Ed.), Pierre Bourdieu: Key concepts (pp. 67-81). Durham, UK: Acumen.

West, C. \& Zimmerman, D.H. (1987). Doing gender. Gender \& Society, 1(2), 125-51.

Woodward, R. (2000). Warrior heroes and little green men: Soldiers, military training, and the construction of rural masculinities. Rural Sociology, 65(4), 640-657.

Woodward, R., \& Neil Jenkings, K. (2011). Military identities in the situated accounts of British military personnel. Sociology, 45(2), 252-268.

Won, S. Y. (2016). State policy? Traditional gender stereotypes? Relative contributions of factors affecting positive work-family interface for working mothers in Korea. Gender, Work \& Organization, 23(2), 147-164.

\section{Tables and Figures}

Table 1

Participants Profiles

\begin{tabular}{|c|c|c|c|c|c|c|}
\hline ID & Age & $\begin{array}{l}\text { Education } \\
\text { Level }\end{array}$ & $\begin{array}{l}\text { Military } \\
\text { Profile }\end{array}$ & Business/Industry Profile & Rank & $\begin{array}{l}\text { Work } \\
\text { Experience }\end{array}$ \\
\hline M1 & 29 & Bachelor & Army & Information Technology & $\begin{array}{l}\text { Assistant } \\
\text { Manager }\end{array}$ & 5 \\
\hline M2 & 28 & Bachelor & Army & Human Resource Development & Employee & 2 \\
\hline M3 & 30 & Bachelor & Air Force & Automobile Manufacturing & $\begin{array}{l}\text { Assistant } \\
\text { Manager }\end{array}$ & 6 \\
\hline M4 & 34 & Bachelor & Auxiliary & Human Resource Development & Manager & 5 \\
\hline M5 & 30 & Bachelor & $\begin{array}{l}\text { Policeman } \\
\text { Army }\end{array}$ & Pharmaceutical & Employee & 3 \\
\hline M6 & 31 & Bachelor & Air Force & Information Technology & $\begin{array}{l}\text { Assistant } \\
\text { Manager }\end{array}$ & 6 \\
\hline M7 & 34 & Bachelor & Army & Civil Engineering & $\begin{array}{l}\text { Assistant } \\
\text { Manager }\end{array}$ & 7 \\
\hline M8 & 33 & Master & Army & Pharmaceutical & $\begin{array}{l}\text { Assistant } \\
\text { Manager }\end{array}$ & 8 \\
\hline M9 & 33 & Bachelor & Air force & Insurance & $\begin{array}{l}\text { Assistant } \\
\text { Manager }\end{array}$ & 7 \\
\hline M10 & 31 & Bachelor & Army & Construction & Manager & 6 \\
\hline M11 & 34 & Bachelor & Army & Communication Business & Manager & 8 \\
\hline M12 & 35 & Master & Army & Consulting / Urban planning & Manager & 7 \\
\hline M13 & 32 & Bachelor & Army & Franchise / Retail & $\begin{array}{l}\text { Assistant } \\
\text { Manager }\end{array}$ & 6 \\
\hline M15 & 33 & Bachelor & Army & Information Technology & $\begin{array}{l}\text { Assistant } \\
\text { Manager }\end{array}$ & 6 \\
\hline M16 & 31 & Bachelor & Army & Cosmetic / Strategic planning & Employee & 5 \\
\hline M17 & 33 & Bachelor & $\begin{array}{l}\text { Auxiliary } \\
\text { Policeman }\end{array}$ & Financial / Securities Brokerage & $\begin{array}{l}\text { Assistant } \\
\text { Manager }\end{array}$ & 6 \\
\hline M18 & 32 & Bachelor & Auxiliary & Information Technology & $\begin{array}{l}\text { Assistant } \\
\text { Manager }\end{array}$ & 6 \\
\hline M19 & 33 & Bachelor & $\begin{array}{l}\text { Policeman } \\
\text { Army }\end{array}$ & IT Construction & $\begin{array}{l}\text { Assistant } \\
\text { Manager }\end{array}$ & 6 \\
\hline M20 & 33 & Bachelor & Air Force & Chemical / R\&D & $\begin{array}{l}\text { Assistant } \\
\text { Manager }\end{array}$ & 6 \\
\hline
\end{tabular}


This is an author-produced, peer-reviewed version of this article. The final, definitive version of this document can be found online at Gender, Work, \& Organization, published by John Wiley \& Sons, Ltd. Copyright restrictions may apply. doi: $10.1111 / g$ wao. 12358

\section{Figures}

First-Order Codes

Worshipping physical strength and macho behavior
Defiant attitude toward the existing order of system

Resistant to the pseudo-military culture and persistent to individualoriented behavior

Respecting veteran students' attitude and behavior

Taking unconditional acceptance of order

Being part of the hierarchical and collective system

Experiencing leadership position with responsibility and powe

Constructing the new image of manhood with leadership and competitive advantage

Discarding the previous image of masculinity

Exhibiting agentic behaviors and leadership acquired through the military experience

Identifying the structural similarities between military and college

Reflexivity on militaristic thought and behavior

Adjusting masculine behaviors in a more socially acceptable manner

Acknowledging the need for the militaristic compliance in workplace

Confirming the structural similarities between military and workplace

Using militaristic compliance as an effective strategy for adjustment

Seeing co-workers with veteran status as allies.

Seeing co-workers with non-veteran status as misfits or incompetent
Second-Order Categories

Pursuing a raw image of masculinity

Having ambivalent feelings

toward the militaristic

behaviors

Internalizing the militaristic compliance through the military experience

Separation from the previous image and pursuit of agentic behaviors

$\overrightarrow{2}$

Practicing the military masculinity

Tailoring the military masculinity

Transferring and legitimizing military masculinity at work

Making distinctions between co-workers based on the militaristic compliance

\section{Figure 1. Identified Codes and Categories}

Note: we adopted the data structure in the analysis from the previous work of Corley and Gioia (2004). 
This is an author-produced, peer-reviewed version of this article. The final, definitive version of this document can be found online at Gender, Work, \& Organization, published by John Wiley \& Sons, Ltd. Copyright restrictions may apply. doi: 10.1111/gwao.12358

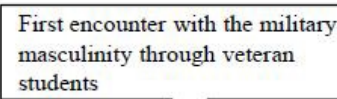

Phase 1

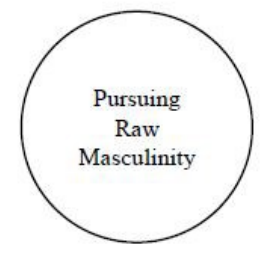

College as Pre Military Space

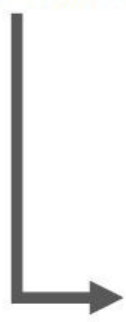

Resisting and Respecting

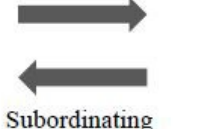

Practicing

Providing a space for practicing

and tailoring military masculinity

as a dominant, leading group

Subordinating

Phase 3

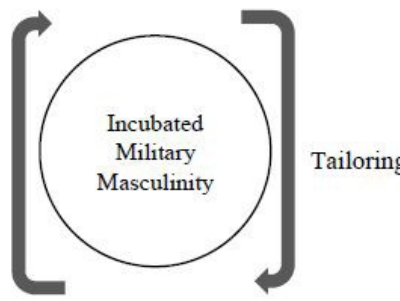

College as Post Military Space

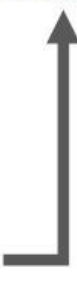

from

the previous

masculinity

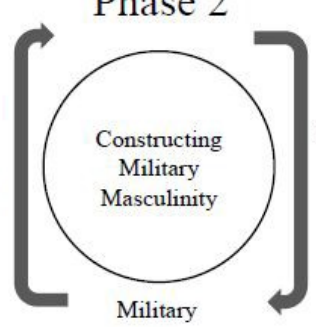

the militaristic

complia

Leadership

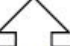

Providing strong socialization process

through military training and life in

barracks

Figure 2

A Model of Military Masculinity Construction and Capitalization of Korean men

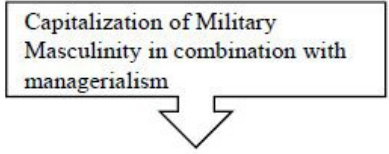

Phase 4

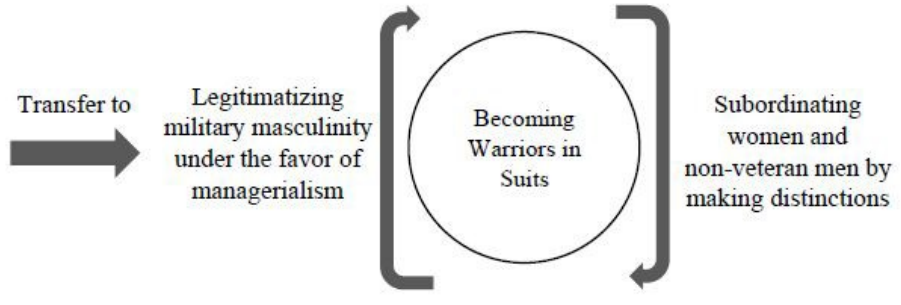

Workplace

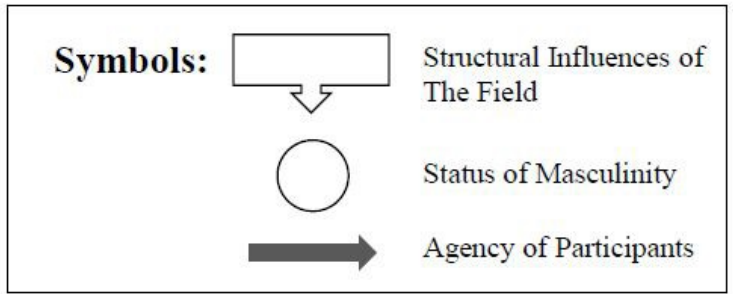

